ADVANCE RESEARCH JOURNAL OF C $\mathbf{R}$ (6) $\mathbf{P}$ I M P R O V E M E N T Volume $\mathbf{8}$ | Issue 2 | December, 2017 | 123-139 $\bullet \bullet \bullet \bullet$ e ISSN-2231-640X

DOI :

10.15740/HAS/ARJCI/8.2/123-139

Visit us: www.researchjournal.co.in

\section{Nutrient management for Brassica juncea L. Czernj. and Cosson in moong-maize mustard cropping system}

\author{
RAVINDRA ROJ, DEVENDRA SINGH ${ }^{1}$ AND BHANWAR LAL JAT ${ }^{2}$
}

\begin{abstract}
The available nitrogen, phosphorus and potassium were $203 \mathrm{~kg}, 18 \mathrm{~kg}$ and $283 \mathrm{~kg} /$ ha, respectively. There were ten treatments viz., $\mathrm{T}_{1}$ (Control), $\mathrm{T}_{2}(100 \% \mathrm{PK}), \mathrm{T}_{3}(100 \% \mathrm{NPK}), \mathrm{T}_{4}$ (150\% NPK), $\mathrm{T}_{5}(100 \% \mathrm{NPK}+\mathrm{S}), \mathrm{T}_{6}\left(100 \% \mathrm{NPK}+\mathrm{Zn} @ 25 \mathrm{~kg} \mathrm{ZnSO}_{4} / \mathrm{ha}\right), \mathrm{T}_{7}(100 \% \mathrm{NPK}+\mathrm{B} @$ $1 \mathrm{~kg} \mathrm{~B} / \mathrm{ha}), \mathrm{T}_{8}(100 \% \mathrm{NPK}+\mathrm{FYM} @ 2.5 \mathrm{t} / \mathrm{ha}), \mathrm{T}_{9}(100 \% \mathrm{NP})$ and $\mathrm{T}_{10}(100 \% \mathrm{NK})$ with the RDF of 120:40:20kg N, $\mathrm{P}_{2} \mathrm{O}_{5}$ and $\mathrm{K}_{2} \mathrm{O} / \mathrm{ha}$, respectively. Plant height did not differ significantly at all the stages of crop growth. Maximum plant height at all the stages of crop growth was recorded under the application of 100\% NPK + FYM @ $2.5 \mathrm{t} / \mathrm{ha}\left(\mathrm{T}_{8}\right)$ treatment. However, minimum plant height at all stages of crop growth was recorded under control $\left(\mathrm{T}_{1}\right)$ treatment. Dry matter accumulations per plant in relation to different fertility levels were found to be significant during all the stages of crop growth, except at harvest. Maximum dry matter accumulation occurs under 100\% NPK + FYM @ 2.5t/ha $\left(\mathrm{T}_{8}\right)$ treatment followed by $100 \% \mathrm{NPK}+\mathrm{S}\left(\mathrm{T}_{5}\right)$ and minimum dry matter accumulation occurs under control (Ti) treatment, respectively. Significantly higher number of secondary branches recorded under 100\% NPK +FYM @ 2.5t/ha $\left(\mathrm{T}_{8}\right)$ treatment at all the stages of crop growth and minimum number of secondary branches recorded under control (Ti) treatment, respectively. Higher number of all the yield attributes was found fewer than 100\% NPK + FYM @ 2.5t/ha $\left(\mathrm{T}_{8}\right)$ treatment and minimum number of all the yield attributes was found under control $\left(\mathrm{T}_{1}\right)$ treatment. Higher values of seed yield, stover yield, biological yield and harvest index was recorded under the application of 100\% NPK + FYM @ $2.5 \mathrm{t} / \mathrm{ha}\left(\mathrm{T}_{8}\right)$ treatment and minimum value was recorded under the application of control $\left(\mathrm{T}_{1}\right)$ treatment. The maximum nutrient uptake by the crop was recorded under the 100\% NPK + FYM @ 2.5t/ha $\left(\mathrm{T}_{8}\right)$ treatment and lowest nutrient uptake by the crop was recorded under the control (Ti) treatment. Maximum oil content was found under $100 \% \mathrm{NPK}+\mathrm{S} @ 40 \mathrm{~kg} / \mathrm{ha}\left(\mathrm{T}_{5}\right)$ treatment but maximum oil yield was recorded under 100\% NPK + FYM @ 2.5t/ha $\left(\mathrm{T}_{8}\right)$ treatment. However, lowest oil content and oil yield was recorded under control (Ti) treatment. Maximum protein content was found under 100\% NPK + FYM @ 2.5t/ha $\left(\mathrm{T}_{8}\right)$ and 150\% NPK $\left(\mathrm{T}_{4}\right)$ treatment but maximum protein yield was found under 100\% NPK + FYM @ 2.5t/ha $\left(\mathrm{T}_{8}\right)$. However, lowest protein content and protein yield was recorded under control $\left(\mathrm{T}_{1}\right)$ treatment. The maximum gross return and net return was obtained under 100\% NPK +FYM @ 2.5t/ha $\left(\mathrm{T}_{8}\right)$ but maximum B : C ratio was found under $100 \% \mathrm{NPK}+\mathrm{B} @ 1 \mathrm{~kg} \mathrm{~B} / \mathrm{ha}\left(\mathrm{T}_{7}\right)$ treatment and lowest grass return, net return and $\mathrm{B}: \mathrm{C}$ ratio was obtained under control treatment $(\mathrm{Ti})$.
\end{abstract}

KEY WORDS : NPK, FYM, Protein content, Oil content, Nutrient management

How to cite this paper : Roj, Ravindra, Singh, Devendra and Jat, Bhanwar Lal (2017). Nutrient management for Brassica juncea L. Czernj. and Cosson in moong-maize mustard cropping system. Adv. Res. J. Crop Improv., 8 (2) : 123-139, DOI : 10.15740/HAS/ARJCI/8.2/123-139.

Paper History : Received : 03.06.2017; Revised : 17.10.2017; Accepted : 02.11.2017
RAVINDRA ROJ

Department of Agriculture, Bhagwant University, AJMER (RAJASTHAN) INDIA

Email : rojravindra@gmail.com 